\title{
Antimicrobial Activity of Bauhinia Purpurea (L) by Minimum Inhibitory Concentration (MIC) Method
}

\author{
${ }^{1 *}$ Shamala T, ${ }^{1}$ A.M.Krupanidhi, ${ }^{2}$ Shanmukhappa S, ${ }^{2}$ B.E.Basavarajappa \\ ${ }^{1}$ Jayamma kulkarni \\ $1 * J a i n$ Institute of Technology, Davangere- \\ 1 Bapuji Pharmacy College, Davangere- \\ 2 Bapuji Institute of Engineering and Technology, Davangere
}

\begin{abstract}
MIC methods are widely used in the comparative testing of new agents, or when a more accurate result is required for clinical management. As there are no CLSI (formerly NCCLS) recommendations for the determination of MICs of varies bio-compounds against gram positive and gram negative organisms. The minimum inhibitory concentration is the lowest concentration (in $\mu \mathrm{g} / \mathrm{ml}$ ) of an antibiotic that inhibits the growth of a given strain of bacteria. In Diagnostic laboratories these MIC'S are used to confirm resistance and also most often used to determine antimicrobial invitro activity. In the present MIC method, one can get the information about Antibiotic agent, preparation of stock solutions, media and inoculation, conditions of incubation, ultimately reading and interpretation of results. The present study is focused to evaluate antibacterial activities of ethanolic extract and purified fractions of Bauhinia purpurea using a gram-positive and a gram-negative organisms Staphylococcus aureus, Klebsiella, E.coli and enterococcus.
\end{abstract}

Keywords: Antimicrobial activity MIC, Cefixim, Bauhinia purpurea (L), column-chromatography

\section{Introduction}

It is a well known fact that the interactions between microorganisms, plants and animals are natural and constant. The ecological role of microorganisms and their importance in the bio-geochemical cycles in nature is well documented. The human food supply consists basically of plants and animals or products derived from them. Microorganisms are ubiquitous and are so small that they can only be visualized with the aid of highresolution microscopes. Microbes are a heterogeneous group of several classes of living things. These were originally classified under the plant and animal kingdoms. Antimicrobial activity and are a source of powerful drugs [1].The present research work on these local medicinal plants like Bauhinia purpurea (BP) is expected to reveal the Antimicrobial potency against the test organisms [2]. The phytoconstituents like flavonoids, Isoflavonoids found in the plant. They may be the responsible active moieties exhibiting the anti microbial activities [3, 4].

\section{Materials and Methods}

\section{A] Preparation of Agar media and Agar dilution plates [5,6,7] :}

Nutrient agar weighing $28 \mathrm{~g}$ is diluted in $1000 \mathrm{ml}$ of distilled water and is subjected to autoclave process for $15 \mathrm{~min}$ at $121^{\circ} \mathrm{C}$. Allow it to cool. Add $19 \mathrm{ml}$ of cooled molten agar to each container, including the antibiotic free control.It is mixed well before pouring into $90 \mathrm{~mm}$ petridishes.After pouring the agar along with extract, fraction and cefixim with $0.1,0.2,0.3$ and $0.4 \mu \mathrm{g}$ each into petridish.Later incubation is done for $10 \mathrm{~min}$.

\section{B] Preparation of Inoculum:}

The procedure describes a method for preparing the desired inoculums by comparision with a $0.5 \mathrm{Mc}$ Farland standard. [0.5ml of $0.048 \mathrm{BaCl}_{2}$ in $99.5 \mathrm{ml}$ of $0.18 \mathrm{M} \mathrm{H}_{2} \mathrm{SO}_{4}$ with constant stirring].The density of organism suspension was adjusted to equal that of the $0.5 \mathrm{Mc}$ Farland standard. Broth is incubated at $35-37^{\circ} \mathrm{C}$ for 3-4 $\mathrm{hr}$ until the visible turbidity is equal to $0.5 \mathrm{Mc}$ farland. Comparision of test and standard against white background with a contrasting blackline, in which suspensions was equal to $1.5 \times 10^{8} \mathrm{CFU} / \mathrm{ml}$.Further $1-2 \mu \mathrm{g}$ of broth is inoculated in agar media.

C] Test organisms used:

The strains used for the present test were: E.coli, S.aureus, Klebsiella and Enterococcus 


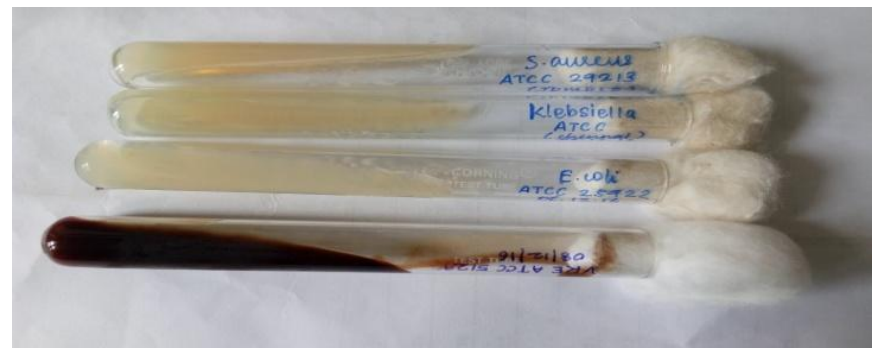

Fig.1:

\section{D] Determination of Minimum Inhibitory Concentration:}

The MIC was observed after overnight incubating the petridishes containing test organisms in agar media along with extract and fraction (F1) of Bauhinia purpurea (L) plant for $16-18 \mathrm{~h}$ at $35-37^{\circ} \mathrm{C}$. The lowest concentration of the sample required to inhibit the growth of test organism was noted for each organism as the minimum inhibitory concentration (MIC). The extract and fraction (F1) were dissolved in dimethylsulphoxide (DMSO).

\section{Results and Discussions}

The preliminary phytochemical test of stem bark extract and fraction of Bauhinia purpurea (L) plant has been revealed that the presence of secondary metabolites like Flavonoids, isoflavonoids has the potency against many microorganisms.[8][9] Results of the antimicrobial activity of the plant extract and fraction1 are shown in table1(fig.2)

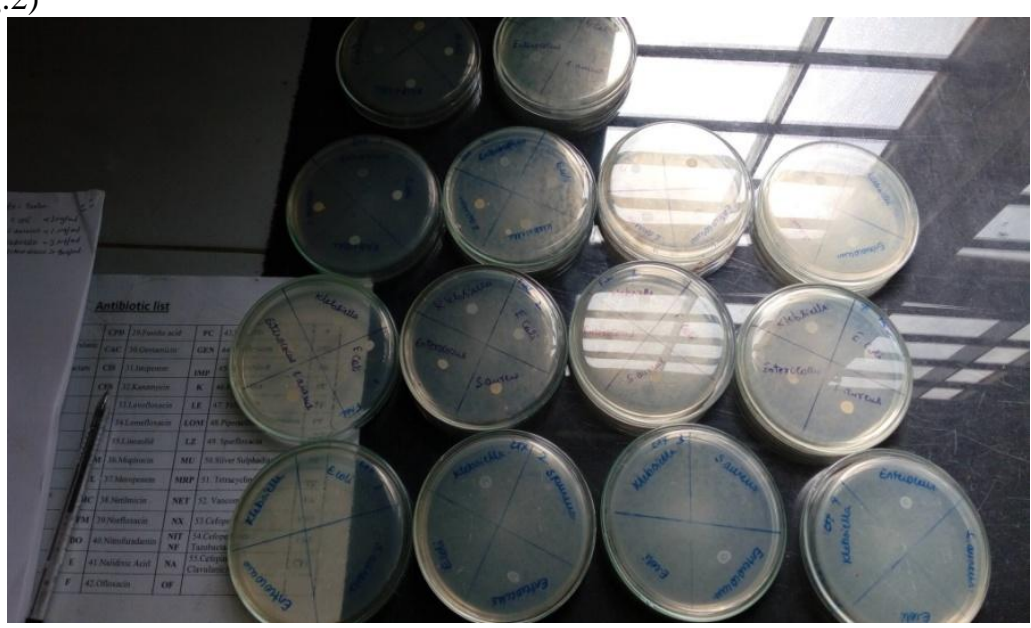

Fig.2

Table1: Results of Minimum Inhibitory Concentration ethanolic extract and isolated fraction of Bauhinia purpurea

\begin{tabular}{|c|c|c|c|c|c|}
\hline \multirow{2}{*}{ SL.NO } & \multirow{2}{*}{ Organisms } & \multirow{2}{*}{$\begin{array}{c}\text { Drug Concentration } \\
\text { In } \mu \mathrm{g}\end{array}$} & \multicolumn{3}{|c|}{ Antibacterial activity by MIC method } \\
\hline & & & $\begin{array}{l}\text { BP- Ethanolic } \\
\text { extract }\end{array}$ & BP-fraction 1 & Cefixime \\
\hline 1 & E.coli. & $\begin{array}{l}10 \\
20 \\
30 \\
40\end{array}$ & $\begin{array}{l}- \\
+ \\
+ \\
+\end{array}$ & $\begin{array}{l}- \\
+ \\
+ \\
+\end{array}$ & $\begin{array}{l}+ \\
+ \\
+ \\
+\end{array}$ \\
\hline 2 & S.aureus & $\begin{array}{l}10 \\
20 \\
30 \\
40\end{array}$ & $\begin{array}{l}- \\
+ \\
+ \\
+\end{array}$ & $\begin{array}{l}- \\
- \\
+ \\
+\end{array}$ & $\begin{array}{l}+ \\
+ \\
+ \\
+\end{array}$ \\
\hline 3 & Enterococcus & $\begin{array}{l}10 \\
20 \\
30 \\
40\end{array}$ & $\begin{array}{l}- \\
+ \\
+\end{array}$ & $\begin{array}{l}- \\
+ \\
+ \\
+\end{array}$ & $\begin{array}{l}+ \\
+ \\
+ \\
+\end{array}$ \\
\hline 4 & Klebsiella & $\begin{array}{l}10 \\
20 \\
30 \\
40 \\
\end{array}$ & $\begin{array}{l}- \\
- \\
+ \\
\end{array}$ & $\begin{array}{l}- \\
- \\
+\end{array}$ & $\begin{array}{l}+ \\
+ \\
+ \\
+\end{array}$ \\
\hline
\end{tabular}

Indications: '++' $\longrightarrow$ Inhibition of growth

$c_{-} \cdot \rightarrow$ No inbibition 
The ethanolic extract and isolated fraction (30mgand 40mg) of Bauhinia purpurea exhibits an excellent antimicrobial activity by MIC method against S.aureus and Klebsiella. Where as the same extract fraction (20mg and 30mg) showed least antimicrobial activity against E.coli and Enterococcus.

\section{Conclusion}

The MIC test is relatively straight forward, which naturally can be done on a very small scale without using much antimicrobial agent. In this current investigation, the results revealed that both extract and isolated fraction are exhibited antimicrobial activity. Considerable minimum inhibitory concentration of extract and isolated fraction was observed showed antimicrobial activity against E.coli and Enterococcus when compared to the standard drug.

\section{References}

[1]. D.Kubmarawa, G.A.Ajoku, N.M.Enweram, D.A.Okorie (2007).Preliminoryphytochemical and antimicrobial screening of 50 medicinal plants from Nigeria. African Journal of Biotechnology. Vol.6(14);pp 1690-1696.

[2]. Srivastava.J,Lambert J,Vietmeyer N(1996).Medicinal plants:An expanding role in development.World Bank Technical paper.NO.320.

[3]. Ghani.A(1990).Introduction to pharmacognosy.Ahmadu Bello University Press.Ltd.Zaria,Nigeria.pp.45-47,187-197.

[4]. Dobelis in(1993).Magic and Medicine of plants.The Readers Digest Association Inc.Pleasant,New York, Montreal.pp 8-48.

[5]. Green RJ(2004).Antioxidant Activity of Plant Tissues.Masters thesis. North Carolina State University.USA.

[6]. Parekh et.al,(2005).Efficacy of Aqueous and Methanol Extracts of some Medicinal Plants for Potential Antibacterial Activity.Turk.J.Biol.29:203-210.

[7]. Lourens ACU, Reddy D, Baser KHC,Viljoen AM,Van Vuuren SF(2004).Invitro biological activity and essential oil composition of four indigenous South African Helichrysum species.J.Ethnopharmacol.9:253-258.

[8]. Lutterodt GD,Ismail A,Basheer RH,Baharuddin H.M.Antimicrobial effects of Psidium guajava extracts as one mechanism of its antidiarrhoel action.Malaysian J Med sci 1999;6(2):17-20.

[9]. Marjorie MC.Plant products as antimicrobial agents.Clin Microbial Rev1999.,12940:564-582

[10]. JH Doughari(2006).,Antimicrobial Activity of Tamarindus indica Linn.Tropical Journal of Pharmaceutical Research,vol 5(2):597603. 